\title{
Positive Impact of COVID19 on Indian Ecosystem: A Brief Review
}

\author{
Agnibha Das Majumdar* \\ Depatment of Physics, School of Chemical Engineering and Physical Sciences, Lovely Professional University, Punjab-144411* \\ Anannya Das \\ Department of Geography, Bagbazar Women's college, University of Calcutta, \\ Khirode Vidyavinode Ave, Baghbazar, Kolkata-700003
}

\begin{abstract}
In the present days, COVID-19 (SARS-Cov-2) has a serious issue and has created many challenges not only in the medical research but also in human life style. This virus has spread out within India also after originated from China and the rate of transmission inrease day by day. India has seen over 8 lakh cases of infections and over 20,000 cases of death till first week of July, 2020. Government of India has announced absolute lockdown to reduce the transmission rate. The present review study indicates a comparative study on the natural activity regarding the air and the water pollution before and after this lockdown. The study has presented the literature about the variation of concentration of pollutant in the air and water. The studies have been conducted and explained the scenario of the Indian ecology.
\end{abstract}

Keywords: Air pollution, COVID-19, Environment, Water pollution.

\section{INTRODUCTION}

China has reported the case of severe pneumonia due to some uncetrtain and unknown reason in December, 2019 at the Wuhan City, Hubei. On 31st December onwards it has declared as the outbreak and World Health Organisation (WHO) has announced this as pandemic. The cause of pandemic was a virus that is SARS-Cov-2 (Commonly known as coronavirus) and scientists and researchers have named it as COVID-19. As per the latest report of the WHO has confirmed total 5,206,614 infected and 337,736 deathe cases respevctively till the date of 23rd May, 2020 within all over the world [1]. Government of India has also declared an absolte lockdown on 24th March, 2020 to reduce the transmission of the coronavirus throughout the civilization. All transporation, industrial activities, commercial activities have been closed. However, "every crisis has a silver lining around the dark cloud and serves as a learning opportunity", and here nature had grown positively in its own way during this lockdown period. Nature had given some positive response and hydrosphere, biosphere and atmosphere has improved some natural activities. Nature has flourished through out the pandemic session as no industrial or civilian activities are active. Air and water pollution are the two major pollutions and have and impact on the biodiversity.

This review article depicts about the nourishment of air and water activity with decreament of major pollutants.

*Corresponding author email:- agnibhadasmajumdar@gmail.com

\section{POSITIVE EFFECT OF COVID-19 ON THE INDIAN ECOSYSTEM}

\section{A. Air Pollution}

In todays daily life, air pollution has achieved the increasing attention and the environmentalists are really concerned about this issue. In India it is a also serious issue, as India is a developing country. It has number of industries, dense popularity. After 1990's India has a growth on the industrialization and also achieved so many economical developements. This growth also has gifted high risk air pollution level to human civilization. World Health Organisation (WHO) and Central Pollution Control Board (CPCB) has declared the most polluted air quality standard of the Indian cities among the top 20 within all over the world. In the year of 2015, near about one million Indian citizens has lost their life due to particulate matter (PM) pollution, which is mostly dominated pollutant within the India. The source of this pollutant is from vehicle, dust, industrial belt and residentials. National Clean Air Programme (NCAP) has launched a 5-years action plan in the year of 2019 with the agenda of $\mathrm{PM}$ reduction.

India has the major busiest cities within all over the parts i.e., Amritsar, Faridabad, Jodhpur, Delhi, Agra, Kanpur (North), Kolkata, Patna, Gaya, Puri (East), Hyderabad, Bengaluru, Chennai, Thiruvanantapuram (South) and Pune, Ahmedabad, Mumbai, Nagpur (West). Those major cities having several pollutants like PM2.5, PM10, Ozone (O3), Sulphur Dioxide (SO2) and Nitrogen Oxide (NOx) etc. within their air. During the lockdown period (i.e. from 16th March to14th April) the PM2.5 and NOx pollutant has decreased in a large manner among the above busiest cities. PM2.5, PM10, NO, $\mathrm{O} 3$ and NO2 has decreased significantly in the northern and southern part of India. But there exists a slight increment of SO2 content of the same air, due to no restric-

\section{American Journal of Physical Sciences and Applications US:ISSN 2644-0792}


tions in coal power plant as this is essential need. East India is only having a decreament in CO content. Excessive risk pollutants has dcreased drastically which were having bad impact on envieonment. Air Quality Index has also significantly dropped down in the year of 2020 [2]. Different national and interational environmental research agencies have declared "Aerosol" as one of the most significant pollutant. During this lockdown period (March-April), it has been observed that Aerosol Optical Depth (ADO) drastically varried. A comparitive analysis depicts that the aerosol content has the minimum value in 2020 within the last 20 years [3].

\section{B. Water Pollution}

The Ganga and Yamuna are one of the most precious rivers of the Indian subcontinent. It has recieved some mythological values also. During the last several centuries, growth of civilization including different industrialization have been developed along the bank of the Yamuna and the Ganga. Government of India has also launched the "Nomami Ganga Programme" to rescue the river from the different water pollutants. Disolved oxygen (DO) level is a significant parameter for the biodiversity within the aquatic frame. Due to the chemical garbage created from the industry and household and the standing stock of phytoplankton in the water community DO level has drastically decreased within the river ganga. During the lockdown period it has been observed that there is a significant incriment of DO levels in the water of Ganga river within the Kolkata region [4].

The various parameters like the $\mathrm{pH}$ level ( $\mathrm{pH}$ of Yamuna river indicates alkaline liquid), DO level (This parameter responsible for the lives of water body ecosystem), Biological Oxygen Demand level (This parameter indicates the water quality and affects the qualntity of disolved oxygen in water) and Chemical Oxygen Demand level (Indicator of water contamination) has been analysed of the water of Yamuna river within the New Delhi area. All the parameter has reduced with some significant percentage that is 1 to $10 \%, 33$ to $66 \%, 51 \%, 45$ to $90 \%$ and 33 to $82 \%$ respectively of the $\mathrm{pH}, \mathrm{DO}, \mathrm{BOD}$ and COD level [1].

\section{CONCLUSION}

COVID-19 is a pandemic situation all over the world and human civilization are in great danger in present situation. Medical science fight its battel in own way. But social distancing is one of major keypoint to reduce the transmission way somehow. For this purpose, absolute lockdown was a great initiative by the Government of India. During this pandemic lockdown period nature has flourished and respond in a positive way. On a serious note this proves that human civilization with the growing industries and the fast, modern life has destroyed the nature day by day. Present review work indicates that several pollutants associated with the air and the water pollution has significantly decreased and nature has revealed its purest form.
[1] Arif, M., Kumar, R., \& Parveen, S. (2020). Reduction in Water Pollution in Yamuna River due to lockdown under COVID-19 Pandemic

[2] Sharma, S., Zhang, M., Gao, J., Zhang, H., \& Kota, S. H. (2020). Effect of restricted emissions during COVID-19 on air quality in India. Science of the Total Environment, $728,138878$.

[3] Gautam, S. (2020). The influence of COVID-19 on air quality in India: a boon or inutile. Bulletin of Environmental Contamination and Toxicology, 1.

[4] 4. Dhar, I., Biswas, S., Mitra, A., Pramanick, P., \& Mitra, A. COVID-19 Lockdown phase: A boon for the River Ganga water quality along the city of Kolkata. NUJS Journal of Regulatory Studies Special Issue. 